\title{
Electrochemical Behavior of Hexamethylbenzene Isocloso Ruthenium-Borane Complex at a Glassy Carbon Electrode in Non-Aqueous Medium
}

\author{
M. M. Ghoneim and I. S. El-Hallag* \\ Analytical \& Electrochemistry Research Unit, Chemistry Department, Faculty of Science, \\ Tanta University, Tanta 31527, Egypt
}

\begin{abstract}
O comportamento eletroquímico do complexo rutênio-borano $\left[\left(\mathrm{C}_{6} \mathrm{Me}_{6}\right)\right.$-isocloso-1- $\left.\mathrm{RuB}_{9} \mathrm{H}_{9}\right]$ foi investigado utilizando um eletrodo de carbono vítreo em $0,1 \mathrm{~mol} \mathrm{~L}^{-1}$ de perclorato de tetrabutil amônio dissolvido em cloreto de metileno, utilizando um intervalo de temperatura entre $-20^{\circ} \mathrm{C} \leq \mathrm{T} \leq 21{ }^{\circ} \mathrm{C}$. Utilizaram-se técnicas de voltametria cíclica convolutiva, cronoamperometria e cronopotenciometria. Os parâmetros químicos e eletroquímicos dos complexos investigados foram determinados e confirmados por métodos de simulação digital. O coeficiente de difusão a temperaturas baixas e a cinética heterogênea de transferência de elétrons do complexo $\left[\left(\mathrm{C}_{6} \mathrm{Me}_{6}\right)\right.$ isocloso-1- $\mathrm{RuB}_{9} \mathrm{H}_{9}$ ] foram relatadas. Com base nos dados obtidos, a reação de eletrodo do complexo $\left[\left(\mathrm{C}_{6} \mathrm{Me}_{6}\right)\right.$-isocloso-1- $\left.\mathrm{RuB}_{9} \mathrm{H}_{9}\right]$ foi sugerida e discutida.
\end{abstract}

Electrochemical behavior of hexamethylbenzene isocloso ruthenium-borane complex $\left[\left(\mathrm{C}_{6} \mathrm{Me}_{6}\right)\right.$-isocloso-1- $\left.\mathrm{RuB}_{9} \mathrm{H}_{9}\right]$ was investigated at a glassy carbon electrode in $0.1 \mathrm{~mol} \mathrm{~L}^{-1}$ tetrabutyl ammonium perchlorate dissolved in methylene chloride, at $-20^{\circ} \mathrm{C} \leq \mathrm{T} \leq 21{ }^{\circ} \mathrm{C}$ using convolutive cyclic voltammetry, chronoamperometry and chronopotentiometry techniques. The chemical and electrochemical parameters of the investigated complex have been determined and confirmed via digital simulation method. Low-temperature diffusion coefficient and heterogeneous electron transfer kinetics of the complex $\left[\left(\mathrm{C}_{6} \mathrm{Me}_{6}\right)\right.$-isocloso-1- $\left.\mathrm{RuB}_{9} \mathrm{H}_{9}\right]$ were reported. On the basis of the obtained data, the electrode reaction of the complex $\left[\left(\mathrm{C}_{6} \mathrm{Me}_{6}\right)-\right.$ isocloso-1- $\left.\mathrm{RuB}_{9} \mathrm{H}_{9}\right]$ was suggested and discussed.

Keywords: ruthenium-borane complexe, convolutive voltammetry, chronoamperometry, chronopotentiometry, digital simulation

\section{Introduction}

Metallacarboranes derived from the transition metals represent a large family of aromatic borane derivatives which, when equipped with a radio-metal, are potentially useful in radio-imaging and radiotherapy of tumors. The radiometallacarborane may be localized in tumor by a tumor cell-selective antibody molecule to which it is attached or by other means (biomolecule, liposome). A particular advantage of radiometallacarboranes in these applications is their extraordinarily great kinetic stability and invisibility to enzyme systems which normally degrade organic radio metal carriers (chelates) with release of the radio metal in an unwanted way. Other radio-imaging systems based upon the invincibility of aromatic boranes to enzyme attack involve simple radioiodination of the

*e-mail: ielhallag@yahoo.co.uk ubiquitous nido-7,8- $\mathrm{C}_{2} \mathrm{~B}_{9} \mathrm{H}_{12}^{-}$ion and its derivatives. This is a facile process and the iodine remains fixed to the boron atom to which it is bound. These and other useful systems are described by Hawthorne and Maderna. ${ }^{1}$

Metalla-borane chemistry was developed, particularly by Kennedy and co-workers. ${ }^{2-5}$ [1-(pcym)-isocloso-1$\mathrm{RuB}_{9} \mathrm{H}_{9}$ ] constitute the first structurally characterized 'clean' monometalla example of the parent ten-vertex isocloso metallaborane structural type. ${ }^{6} \mathrm{~A}$ variety of deltahedral metallaborane structures were discovered based on deltahedra topologically distinct from the deltahedra found in simple metal-free boranes and carboranes. Such metallaborane deltahedra are called isocloso structures and can be derived from the closo deltahedron with the same number of vertices by diamond-square-diamond (dsd) rearrangements. ${ }^{7,8}$

The two architectures are related by a diamondsquare-diamond (DSD) change ${ }^{7}$ and their geometries are 


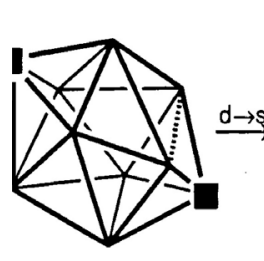

10-vertex closo polyhedron (D4d bicapped square antiprism)

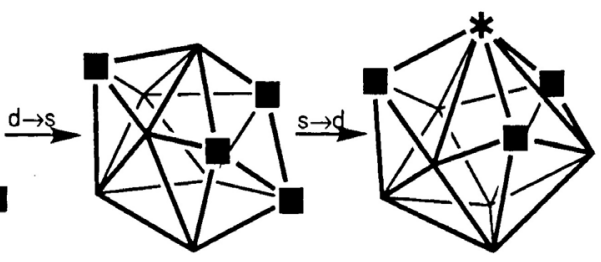

The 10-vertex isonido polyhedron

The (C3v) 10-vertex isocloso polyhedron 10-vertex polyhedra

Scheme 1

conveniently referred to as close and isocloso respectively. The isocloso geometry is a characteristic of metallaboranes that have a metal atom as a cluster constituent in the axial polar 1-position. ${ }^{8}$

Morris and Reed ${ }^{9}$ had analyzed the electrochemical data of simple boron compounds, boranes, metallaboranes, carboranes, and metallacarboranes in view of the formal structural relationship of borane clusters with the number of electron pairs available for bonding. The cyclic voltammetry of $\mathrm{BH}_{3} \mathrm{CN}^{-}$in acetonitrile, ${ }^{10-13}$ shows no obvious oxidation or reduction waves at $\mathrm{Pt}$ electrode, whereas several reactive electrodes (e.g., $\mathrm{Fe}, \mathrm{Cu}, \mathrm{Co}$ and $\mathrm{Ni}$ ) led to the formation of metallacyanoborane derivatives. The electrochemical properties of the octahydrotriborate ion, $\mathrm{B}_{3} \mathrm{H}_{8}^{-}$in acetonitrile and DMF, underwent one-electron oxidation at a platinum or gold anode to give $\mathrm{B}_{3} \mathrm{H}_{7} \cdot \mathrm{N}-\mathrm{CCH}_{3}$ and $\mathrm{B}_{3} \mathrm{H}_{7} \cdot \mathrm{DMF}^{14}$ respectively. The reaction studied chronopotentiometrically and by exhaustive controlled-potential electrolysis. The cyclic voltammogram of $\mathrm{B}_{10} \mathrm{H}_{12}\left(\mathrm{NCCH}_{3}\right)_{2}$ in $\mathrm{CH}_{3} \mathrm{CN}$ at Pt electrode exhibited two irreversible oxidation peaks at $\mathrm{E}_{\mathrm{p}}+0.75$ and $+1.2 \mathrm{~V}\left(\mathrm{Ag} / \mathrm{AgNO}_{3}\right)$ with no well-defined corresponding reduction waves. ${ }^{15}$ However, a broad reduction wave at $\mathrm{E}_{\mathrm{p}}-0.8 \mathrm{~V}$, which appeared only after a scan to anodic potentials, is best interpreted mostly as the reduction of $\mathrm{H}^{+}$. The perhalogenated ions $\mathrm{B}_{9} \mathrm{X}_{9}^{2-}(\mathrm{X}=\mathrm{Cl}$, $\mathrm{Br}, \mathrm{I})$ underwent two successive one-electron reversible oxidation in $\mathrm{MeCN}$ and $\mathrm{CH}_{2} \mathrm{Cl}_{2}$. The initial oxidation was electrochemically reversible $\left(\Delta E_{\mathrm{p}} c a .60 \mathrm{mV}\right.$ at sweep rates of $20-100 \mathrm{mV} \mathrm{s}^{-1}$ ) and chemically irreversible in MeCN but both chemically and electrochemically are reversible in $\mathrm{CH}_{2} \mathrm{Cl}_{2} \cdot{ }^{16,17}$ Voltammograms of $\mathrm{B}_{10} \mathrm{H}_{10}{ }^{2-}$ at a rotating platinum electrode (RPE) exhibited two anodic peaks. The cyclic voltammetry of $\left[\left(\mathrm{B}_{10} \mathrm{H}_{12}\right)_{2} \mathrm{Ni}\right]^{2-}$ in $\mathrm{CH}_{3} \mathrm{CN}$ showed an irreversible oxidation peak at $+1.03 \mathrm{~V}$ ( $v s$. SCE). ${ }^{18}$ Half-sandwich of ruthenacarborane complex $\left[\left(\eta-\mathrm{C}_{5} \mathrm{Me}_{5}\right)\right.$ RuIII $\left.\left\{2-\mathrm{Me}-4,5-\mathrm{Et}_{2}-3,6-\mathrm{Bu}-2,4,5-\mathrm{C}_{3} \mathrm{~B}_{2}\right\}\right]$ in DMF solution exhibits reversible $\mathrm{Ru}(\mathrm{III}) \mathrm{Ru}(\mathrm{II})$ reduction $\left(\mathrm{E}_{2}^{0}=-1.40 \mathrm{~V}\right.$, versus $\mathrm{SCE}) .{ }^{19}$ In metalla-borane chemistry, metal atoms are incorporated into boron cluster which leads to the area of new isocloso and isonido geometries..$^{20,21}$
The convolution theorem finds use in the situation where it is required to perform the inverse transformation on a function which is the product of two functions of the Laplace variable each of which individually have known inverse transformations. In such a situation, the convolution theorem gives 22

$\mathbf{L}^{-1}\left[f_{s}(s) \cdot g_{s .}(s)\right]=\int_{0}^{t} G(u) F(t-u) d u$

in which $f_{s}, g_{s}$ are the Laplace transform of the functions $\mathrm{F}$ and $\mathrm{G}$, the variable $\mathrm{u}$ is a dummy variable which is lost when the definite integral is evaluated.

For the following reaction, in which a given species undergoing only electron transfer

$\mathrm{A}+\mathrm{ne} \rightleftharpoons \mathrm{B}$

and no subsequent processes other than 'linear' diffusion out in the solution from a planar electrode, i.e. the Fick's Second Law is expressed as: $:^{23}$

$\left[\partial \mathrm{C}_{\mathrm{A}} / \partial \mathrm{t}\right]_{\mathrm{x}}=\mathrm{D}_{\mathrm{A}}\left[\partial^{2} \mathrm{C}_{\mathrm{A}} / \partial \mathrm{x}^{2}\right]_{\mathrm{x}}$

then the solution of the above via Laplace Methods yields

$\left(\mathrm{C}^{\text {bulk }}-\mathrm{C}^{\mathrm{s}}\right)=\mathrm{I}_{1} / \mathrm{n} \mathrm{FSD}_{\mathrm{A}}^{1 / 2}$ and

$\mathrm{C}^{\text {bulk }}=\mathrm{I}_{\lim } / \mathrm{n} \mathrm{FSD}^{1 / 2} \mathrm{~A}$

where $\mathrm{C}^{\text {bulk }}$ and $\mathrm{C}^{\mathrm{s}}$ are the bulk and surface concentrations respectively and the convolution $I_{1}$ is given by $I_{1}=i^{*}(\pi t)^{-1 / 2}$ or more 'fully' as:

$I_{1}(t)=\pi^{-1 / 2} \int_{0}^{t} \mathrm{i}(\mathrm{u}) /(\mathrm{t}-\mathrm{u})^{1 / 2} \mathrm{du}$

and $\mathrm{I}_{\lim }$ is the limiting value of $\mathrm{I}_{1}$ at 'extreme' potentials i.e. when the concentration at the electrode $C^{s}$ is effectively reduced to zero by rapid redox conversion and the current is thus controlled solely by the maximum rates of diffusion to (and from) the electrode.

In the case of electron transfer followed by homogeneous decomposition, the species here are produced by electron transfer at a planar electrode and decomposed in the bulk via a first order chemical reaction of rate constant $\mathrm{k}_{\mathrm{c}}$. The Fick's Second Law expression is now ${ }^{23,24}$

$\left[\partial \mathrm{C}_{\mathrm{B}} / \partial \mathrm{t}\right]_{\mathrm{x}}=\mathrm{D}_{\mathrm{B}}\left[\partial^{2} \mathrm{C}_{\mathrm{B}} / \partial \mathrm{x}^{2}\right]_{\mathrm{x}}-\mathrm{k}_{\mathrm{c}} \mathrm{C}_{\mathrm{B}}($ at $\mathrm{x})$

and solution via Laplace methods gives here, necessarily starting at zero concentration in the bulk, the following electrode concentration 
$\mathrm{C}_{\mathrm{B}}^{\mathrm{s}}=\mathrm{I}_{2} / \mathrm{nFAD}^{1 / 2}{ }_{\mathrm{B}}$

where the 'kinetic' convolution $\mathrm{I}_{2}$ is given by ${ }^{24}$

$I_{2}(t)=\pi^{-1 / 2} \int_{0}^{t}\left[i(u) \exp \left(-k_{c}(t-u)\right)\right] /(t-u)^{1 / 2} d u$

Thus in the $\mathrm{I}_{2}$ convolution at time $\mathrm{t}$, each segment of $\mathrm{i}(\mathrm{u})$ is scaled by dividing by the square root of the time which has elapsed from $t$ to the time $u$ to which the segment refers and likewise is scaled by the exponential factor $\exp \left(-\mathrm{k}_{\mathrm{c}}(\mathrm{t}-\mathrm{u})\right)$. Thus $\mathrm{I}_{2}$ for example now goes to a plateau (at zero) on return of the sweep in cyclic voltammetry and this property allows determination of $\mathrm{k}_{\mathrm{c}}$.

Several algorithms have been proposed for the evaluation of the convolution integral $\mathrm{I}(\mathrm{t})$. The following one was used in this work, ${ }^{25-29}$

$I(t)=\frac{1}{\sqrt{ } \pi} \sum_{j=1}^{j=k} \frac{\Gamma(k-j+1 / 2)}{(k-j) !} \Delta t^{1 / 2} i(j \Delta t)$

in which $\mathrm{k}$ is the index of the descrete convoluted current being calculated $(\mathrm{I}(\mathrm{k} \Delta \mathrm{t})), \mathrm{j}$ is the series counter to the discrete current data points $0 \ldots \mathrm{k} ., \Delta \mathrm{t}$ is the time interval between successive data points, and $\Gamma$ (f) is the gamma function of $\mathrm{f}$.

The deconvolution of current can be expressed as the differential of the $I_{1}$ convolution. In more grneral terms deconvolution is akin to semi- differentiation in a similar manner to considering $\mathrm{t}^{-1 / 2}$ convolution as semiintegration. The relationship between $t^{-1 / 2}$ convolutions and deconvolutions is indicated in the following scheme. ${ }^{23}$

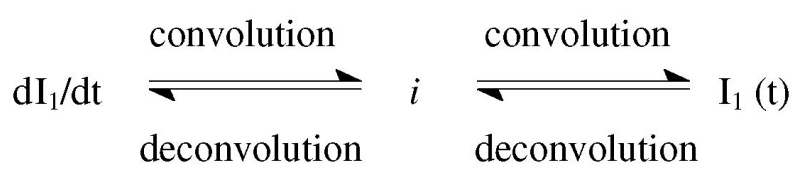

Scheme 2

To date there have been very few electrochemical investigations of hexamethylbenzene isocloso rutheniumborane complex in $\mathrm{CH}_{2} \mathrm{Cl}_{2}$, especially via convolutive voltammetry and digital simulation methods.

In the present work, the electrochemical behavior, nature of the electrode reaction, effect of temperature on kinetic parameters, activation energy barrier and the chemical and the electrochemical parameters of hexamethylbenzene isocloso ruthenium-borane complex $\left[\left(\mathrm{C}_{6} \mathrm{Me}_{6}\right)\right.$-isocloso$\left.1-\mathrm{RuB}_{9} \mathrm{H}_{9}\right]$, at a glassy carbon electrode in non-aqueous medium have been determined and discussed.

\section{Experimental}

\section{Materials and solutions}

The metallaborane complex (hexamethylbenzene isocloso ruthenium-borane complex $\left(\mathrm{C}_{6} \mathrm{Me}_{6}\right)$-isocloso$1-\mathrm{RuB}_{9} \mathrm{H}_{9}$ ) was prepared by and obtained from Dr. Kennedy ${ }^{30}$ at Leeds University. Standard stock solution of $5 \times 10^{-2} \mathrm{~mol} \mathrm{~L}^{-1}$ of the complex under investigation was prepared in $0.1 \mathrm{~mol} \mathrm{~L}^{-1} \mathrm{TBAP} / \mathrm{CH}_{2} \mathrm{Cl}_{2}$. Tetrabutylammonium perchlorate (TBAP) and $\mathrm{CH}_{2} \mathrm{Cl}_{2}$ were analytical grade and used as supplied

\section{Apparatus}

Cyclic voltammetry, convolutive voltammetry, chronoamperometry, and chronopotentiometry experiments were performed using a Princeton Applied Research (PAR) Computer-controlled Potentiostat Model 363 (PAR, Oak Ridge, TN, USA). A micro-electrolysis cell with a three electrode system comprising of a glassy carbon electrode (GCE) as the working electrode, a platinum sheet auxiliary electrode and a silver wire in contact with saturated lithium chloride in $\mathrm{CH}_{2} \mathrm{Cl}_{2} / \mathrm{TBAP}$ as a reference electrode was used. (Fluka AG). The uncompensated electrolyte resistance $\left(\mathrm{iR}_{\mathrm{u}}\right)$ was obtained post data captured via software correction of the potential axis by inserting trial value of $\mathrm{iR}_{\mathrm{u}}$ until the appropriate value of $i R_{u}$ give straight line on the potential axis. All the measurements were automated and controlled through the programming capacity of the apparatus.

\section{Procedure}

A $5 \times 10^{-2} \mathrm{~mol} \mathrm{~L}^{-1}$ solution of $\mathrm{C}_{6} \mathrm{Me}_{6}$-isocloso- $1-\mathrm{RuB}_{9} \mathrm{H}_{9}$ was introduced into the electrolysis cell containing $10 \mathrm{~mL}$ of $0.1 \mathrm{~mol} \mathrm{~L}^{-1}$ tetrabutyl ammonium perchlorate (TBAP) dissolved in methylene chloride and then degassed thoroughly with oxygen-free nitrogen, while an atmosphere of nitrogen was maintained over surface of the solution during the measurements. The electrochemical measurements were performed using cyclic voltammetry, chronoamperometry and chronopotentiometry techniques. The measurements were carried out at temperature ranging from $21^{\circ} \mathrm{C}$ to $-20^{\circ} \mathrm{C}$.

\section{Results and Discussion}

Cyclic voltammetry of $\left[\left(\mathrm{C}_{6} \mathrm{Me}_{6}\right)\right.$-isocloso- $\left.1-\mathrm{RuB}_{9} \mathrm{H}_{9}\right]$
complex

Cyclic voltammogram of $2.5 \times 10^{-3} \mathrm{~mol} \mathrm{~L}^{-1}$ solution of $\left[\left(\mathrm{C}_{6} \mathrm{Me}_{6}\right)\right.$-isocloso-1- $\left.\mathrm{RuB}_{9} \mathrm{H}_{9}\right]$ complex recording in 
Table 1. Values of the kinetic parameters obtained for $\left[\left(\mathrm{C}_{6} \mathrm{Me}_{6}\right)\right.$-isocloso-1- $\left.\mathrm{RuB}_{9} \mathrm{H}_{9}\right]$ complex at a glassy carbon electrode using cyclic voltammetry $(\mathrm{CV})$, convolution (Conv), deconvolution (Deconv) voltammetry, chronoamperometry (CA), chronopotentiometry (CP) and digital simulation (Sim) techniques

\begin{tabular}{|c|c|c|c|c|c|c|c|c|}
\hline \multicolumn{9}{|c|}{ Parameters of the electrode reaction } \\
\hline Technique & $\begin{array}{l}\mathrm{k} \times 10^{3} / \\
\left(\mathrm{cm} \mathrm{s}^{-1}\right)\end{array}$ & $\mathrm{E}^{0^{\prime}} / \mathrm{V}$ & $\begin{array}{l}\mathrm{D} \times 10^{5} / \\
\left(\mathrm{cm}^{2} \mathrm{~s}^{-1}\right)\end{array}$ & $\alpha$ & $\mathrm{k}_{\mathrm{c}} / \mathrm{s}^{-1}$ & $\begin{array}{c}\Delta \mathrm{H}^{\ddagger} / \\
\left(\mathrm{K} \mathrm{J} \mathrm{mol}^{-1}\right)\end{array}$ & $\begin{array}{c}\Delta \mathrm{S}^{\neq} / \\
\left(\mathrm{J} \mathrm{K}^{-1} \mathrm{~mol}^{-1}\right)\end{array}$ & $\begin{array}{c}\Delta \mathrm{G}^{\neq} / \\
\left(\mathrm{K} \mathrm{J} \mathrm{mol}^{-1}\right)\end{array}$ \\
\hline Sim & 3.55 & -1.078 & 4.18 & 0.43 & 0.110 & ---- & ---- & ---- \\
\hline $\mathrm{CV}$ & 3.50 & -1.075 & 4.12 & 0.44 & ---- & 3.57 & -73.25 & 25.39 \\
\hline Conv. & ---- & --- & $\begin{array}{l}4.25^{(\mathrm{a})} \\
4.29^{(\mathrm{b})}\end{array}$ & ---- & 0.112 & --- & --- & --- \\
\hline Decon. & ---- & -1.079 & 4.27 & ---- & ---- & ---- & ---- & ---- \\
\hline $\mathrm{CA}$ & 3.65 & --- & ---- & 0.42 & --- & --- & --- & ---- \\
\hline $\mathrm{CP}$ & ---- & ---- & 4.21 & ---- & ---- & ---- & ---- & ---- \\
\hline
\end{tabular}

${ }^{(a)}$ Value of $\mathrm{D}$ determined from equation 7 and, (b) value of $\mathrm{D}$ determined from equation 8.

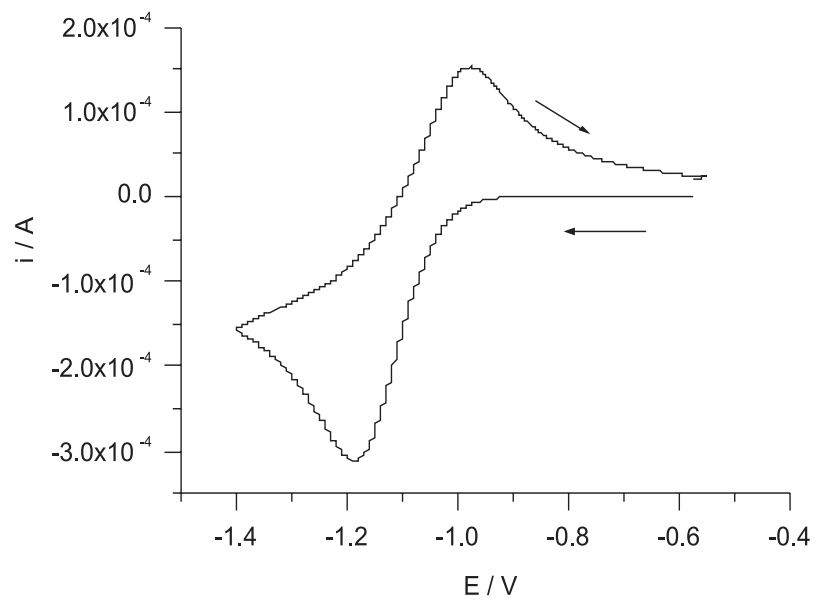

Figure 1. Cyclic voltammogram of $2.5 \times 10^{-3} \mathrm{~mol} \mathrm{~L}^{-1}$ solution of $\left[\left(\mathrm{C}_{6} \mathrm{Me}_{6}\right)-\right.$ isocloso-1- $\mathrm{RuB}_{9} \mathrm{H}_{9}$ ] complex recording in $0.1 \mathrm{~mol} \mathrm{~L}{ }^{-1} \mathrm{TBAP}^{-} \mathrm{CH}_{2} \mathrm{Cl}_{2}$ at a glassy carbon electrode and scan rate of $0.2 \mathrm{~V} \mathrm{~s}^{-1}, \mathrm{~T}=21^{\circ} \mathrm{C}$.

$0.1 \mathrm{~mol} \mathrm{~L}-1$ TBAP $/ \mathrm{CH}_{2} \mathrm{Cl}_{2}$ at a glassy carbon electrode and scan rate of $0.2 \mathrm{~V} \mathrm{~s}^{-1}$ exhibited a single cathodic peak $\left(\mathrm{E}_{\mathrm{pc}}=-1.170 \mathrm{~V}\right)$ associated with an anodic peak $\left(\mathrm{E}_{\mathrm{pa}}=-0.999 \mathrm{~V}\right)$ at $21^{\circ} \mathrm{C}$ (Figure 1). The two coupled peaks indicate a moderate fast chemical reaction following a quasi-reversible electron transfer (EC mechanism). ${ }^{31}$ In the selected range of scan rates $\left(0.05-2 \mathrm{~V} \mathrm{~s}^{-1}\right)$, the difference in the peak potentials $\left(\Delta E_{p}=\mathrm{E}_{\mathrm{pc}}-\mathrm{E}_{\mathrm{pa}}\right)$ is varies between 120.5 to $220.5 \pm 5 \mathrm{mV}$ which is more than the expected value $(58 \mathrm{mV})$ for one-electron Nernstian process. ${ }^{32}$ This may be attributed to the quasi-reversibility rate of electron transfer in addition to some uncompensated solution resistance of the $\mathrm{CH}_{2} \mathrm{Cl}_{2}$ solution. ${ }^{33}$ The formal potential $\left(\mathrm{E}^{0^{\prime}}\right)$ was determined from the average values of the peak potentials position observed in the voltammograms recorded at different scan rates (Table 1). The standard heterogeneous rate constant $\left(\mathrm{k}_{\mathrm{s}}\right)$ was calculated from the voltammograms via peak separation using $\Delta \mathrm{E}_{\mathrm{p}}$ values versus rate constants. ${ }^{34}$ Values of $\mathrm{E}_{\mathrm{p}}-\mathrm{E}_{\mathrm{p} / 2}$ (Table 2) was used for calculation of
Table 2. Peak characteristics of the investigated $\left[\left(\mathrm{C}_{6} \mathrm{Me}_{6}\right)\right.$-isocloso-1$\left.\mathrm{RuB}_{9} \mathrm{H}_{9}\right]$ complex extracted from cyclic, deconvolution voltammetry and digital simulation techniques at $0.2 \mathrm{~V} \mathrm{~s}^{-1}$

\begin{tabular}{lcc}
\hline $\mathrm{E}_{\mathrm{p}}-\mathrm{E}_{\mathrm{p} / 2} / \mathrm{mV}$ & $74^{(\mathrm{a})}$ & $75^{(\mathrm{c})}$ \\
$\mathrm{E}_{\mathrm{p}}-\mathrm{E}^{\mathrm{o}^{\prime}} / \mathrm{mV}$ & $75^{(\mathrm{a})}$ & $76^{(\mathrm{c})}$ \\
$\mathrm{W}^{\mathrm{p}} / \mathrm{mV}$ & $114^{(\mathrm{b})}$ & $113^{(\mathrm{c})}$ \\
$\Delta \mathrm{E}_{\mathrm{p} \text { deconv }} / \mathrm{mV}$ & $74^{(\mathrm{b})}$ & $75^{(\mathrm{c})}$ \\
$\mathrm{e}_{\mathrm{pf}} / \mathrm{e}_{\mathrm{pb}}$ (Deconv) & $1.45^{(\mathrm{b})}$ & $1.45^{(\mathrm{c})}$ \\
\hline
\end{tabular}

${ }^{(a)}$ Values determined from CV, (b) values determined from deconvolution and ${ }^{(c)}$ values determined from digital simulation.

the transfer coefficient $(\alpha)$ via equation 5 and found to be $0.44 \pm 0.01$

$\mathrm{E}_{\mathrm{p}}-\mathrm{E}_{\mathrm{p} / 2}=48 /\left(\alpha \mathrm{n}_{\mathrm{a}}\right)$

where $\mathrm{E}_{\mathrm{p}}$ is the cathodic peak potential and $\mathrm{E}_{\mathrm{p} / 2}$ is the half-peak potential, i.e. the magnitude of the potential at half-height of peak current.

After background subtraction and correction for the uncompensated resistance, the diffusion coefficient $D$ was determined from equation $6,{ }^{32}$

$\mathrm{i}_{\mathrm{p}}=\left(2.99 \times 10^{5}\right) \mathrm{n}\left({\alpha \mathrm{n}_{\mathrm{a}}}\right)^{1 / 2} \mathrm{SC}^{\text {bulk }} \mathrm{D}^{1 / 2} v^{1 / 2}$

where $i_{p}$ is the peak current, $n$ is the number of electrons consumed in electrode reaction, $\alpha$ is the transfer coefficient, $\mathrm{n}_{\mathrm{a}}$ is the number of electron participating in the rate determining step, $\mathrm{S}$ is the electrode surface area, $\mathrm{C}^{\text {bulk }}$ is the bulk concentration of the species, $\mathrm{D}^{1 / 2}$ is the square root of the diffusion coefficient and $v^{1 / 2}$ is the square root of the scan rate. The estimated $\mathrm{D}$ value was found to be $4.12 \pm$ $0.2 \times 10^{-5} \mathrm{~cm}^{2} \mathrm{~s}^{-1}$. 


\section{Convolution-deconvolution voltammetry}

Convolutive voltammetry has been successfully applied to analysis of mechanism of several electrochemical processes. ${ }^{35-41}$ The diffusion coefficient of the investigated complex was determined, after applying background subtraction and correction for uncompensated resistance, from equation $7,{ }^{36}$

$\mathrm{I}_{\text {lim }}=\mathrm{nFSD}^{1 / 2} \mathrm{C}^{\text {bulk }}$

where $I_{\text {lim }}$ is the limiting value achieved for $I_{1}$ when the potential is driven to a sufficiently extreme value past the peak, and the other terms has their usual meanings. The diffusion coefficient was also determined from a simple and accurate method via combination between the definition of both limiting convoluted current and peak current of the cyclic voltammogram using the equation $8,{ }^{37}$

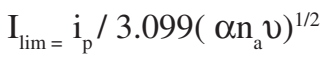

where $i_{p}$ was defined in equation 6 , and the other parameters have their usual meanings. The $\mathrm{I}_{1}$ convolution of the investigated complex illustrated in Figure 2 shows a distinct separation between the forward and reverse sweep and clearly indicates the sluggishness of electron transfer of the reduction process. At low sweep rate, the reverse sweep of the $I_{1}$ convolution does not return to zero due to chemical reaction appears at longer time scales of the experiment. Values of the diffusion coefficient D evaluated via equations 7 and 8 are listed in Table 1 . The homogeneous chemical rate constant $\left(\mathrm{k}_{\mathrm{c}}\right)$ of the chemical step that follows the charge transfer one can be calculated via the kinetic convolution $\left(\mathrm{I}_{2}\right)$ at a sweep rate of $0.2 \mathrm{~V} \mathrm{~s}^{-1}$, which is defined as indicated in equation $3^{38}$ and presented in Figure 3 as calculated from the appropriate value of

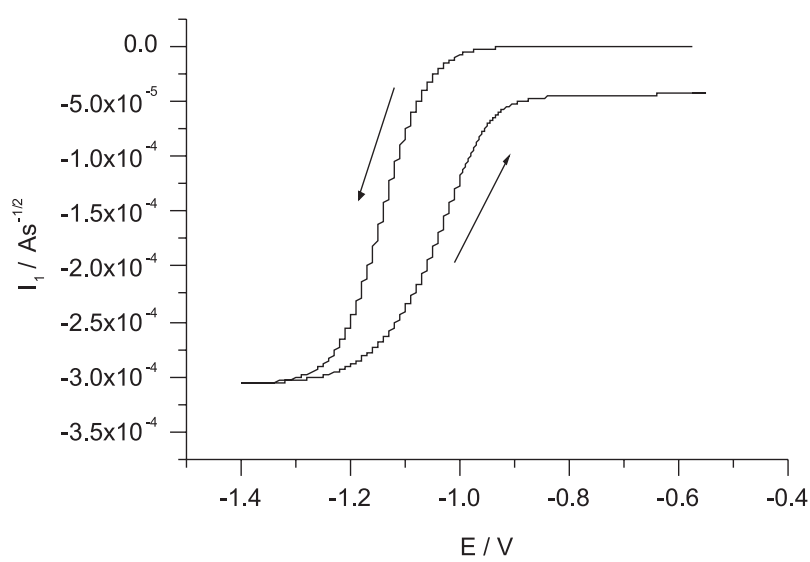

Figure 2. Convoluted current of $\left[\left(\mathrm{C}_{6} \mathrm{Me}_{6}\right)\right.$-isocloso-1- $\left.\mathrm{RuB}_{9} \mathrm{H}_{9}\right]$ complex at glassy carbon electrode, sweep rate $0.2 \mathrm{~V} \mathrm{~s}^{-1}, \mathrm{~T}=21^{\circ} \mathrm{C}$.

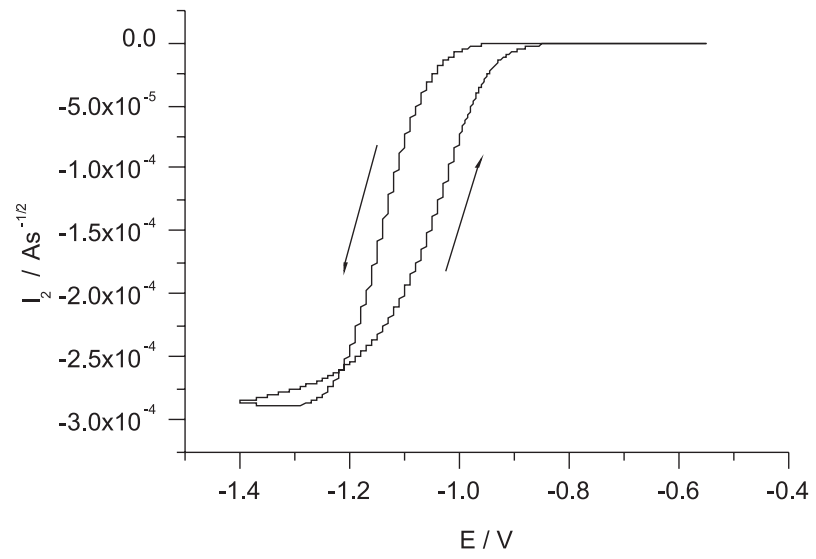

Figure 3. Kinetic convoluted current of $\left[\left(\mathrm{C}_{6} \mathrm{Me}_{6}\right)\right.$-isocloso- $\left.1-\mathrm{RuB}_{9} \mathrm{H}_{9}\right]$ complex at glassy carbon electrode, sweep rate of $0.2 \mathrm{~V} \mathrm{~s}^{-1}, \mathrm{~T}=21^{\circ} \mathrm{C}$.

the chemical rate constant obtained by inserting trial value of the homogeneous chemical rate constant $\left(\mathrm{k}_{\mathrm{c}}\right)$ into the convolution calculation until $\mathrm{I}_{2}$ returned to zero immediately after the peak. This is merely a reflection of the absence of the reductive species at the electrode at potentials before the peak when the bulk concentration of this species is zero. The true $\mathrm{k}_{\mathrm{c}}$ value determined from $\mathrm{I}_{2}$ convolution was found to be $0.112 \mathrm{~s}^{-1}$ which agrees with the value used in simulated cyclic voltammograms.

The values of true $\mathrm{k}_{\mathrm{c}}$ and formal potential $\left(\mathrm{E}^{\mathrm{o}^{\prime}}\right)$ were determined simultaneously from equation $9,37,38$

$\mathrm{I}_{\lim }-\mathrm{I}_{1}=\mathrm{I}_{2} \exp -\left(\left(\mathrm{E}-\mathrm{E}^{\mathrm{o}^{\prime}}\right)(\mathrm{nF} / \mathrm{RT})\right)$

where $\mathrm{F}$ is the faraday constant $\left(96485 \mathrm{C} \mathrm{mol}^{-1}\right), R$ is the universal gas constant $\left(8.314 \mathrm{~J} \mathrm{~K}^{-1} \mathrm{~mol}^{-1}\right), \mathrm{T}$ is the temperature and the other parameters have their usual definations. Presentation of equation 9 in Figure 4 indicates that when $E=E^{o^{\prime}}$, value of $I_{\lim }-I_{1}$ will equals to $I_{2}$, which means that plots of $I_{\lim }-I_{1}$ and $I_{2}$ versus the applied potential, will intersect at $\mathrm{E}^{\mathrm{o}^{\prime}}$ when $\mathrm{k}_{\mathrm{c}}$ value is true.

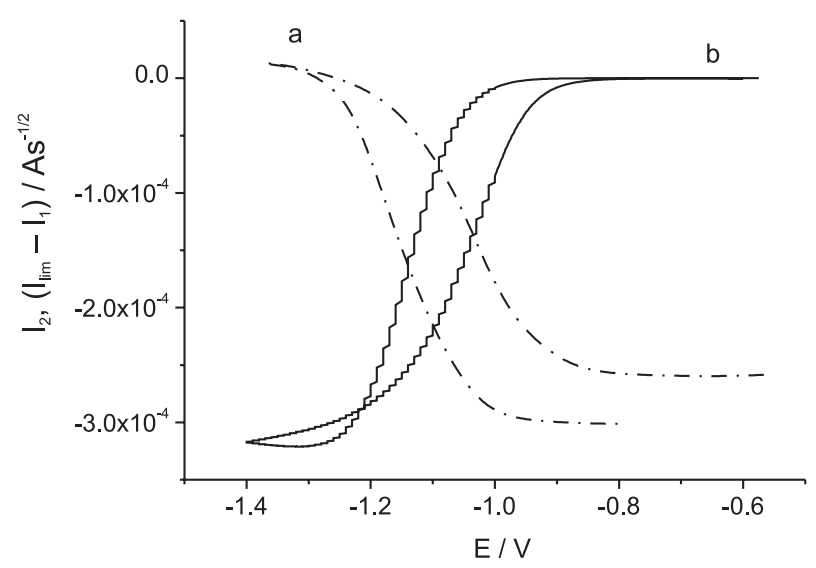

Figure 4. $\mathrm{I}_{\lim }-\mathrm{I}_{1}(\mathrm{a})$ and $\mathrm{I}_{2}$ (b) versus the applied potential of $\left[\left(\mathrm{C}_{6} \mathrm{Me}_{6}\right)\right.$ isocloso-1- $\mathrm{RuB}_{9} \mathrm{H}_{9}$ ] complex at sweep rate of $0.2 \mathrm{~V} \mathrm{~s}^{-1}$. 
The deconvolution transform gives a rapid assessment of either the electron transfer regime or value of $\mathrm{E}^{\mathrm{o}^{\prime}}$. Also, as shown in Figure 5, the different peak heights in the forward and backward sweeps of deconvoluted current $\left(\mathrm{dI}_{1} / \mathrm{dt}\right)$ gives a strong evidence for a chemical reaction following the electron transfer (Table 2). The mean values of the cathodic $\left(\mathrm{E}_{\mathrm{pc}(\mathrm{decon})}\right)$ and anodic $\left(\mathrm{E}_{\mathrm{pa} \text { (decon) }}\right)$ peak potentials were taken as the formal potentials $\left(\mathrm{E}^{\mathrm{o}^{\circ}}\right)$ of the system under consideration. The estimated value of $\mathrm{E}^{\mathrm{o}^{\prime}}$ is given in Table I. The cathodic half-peak width $\left(\mathrm{w}^{\mathrm{p}}\right)$ was taken as a route for knowing the nature of electron transfer. ${ }^{38}$ The calculated values were in the range of $105-140 \mathrm{mV}$ at $v=0.1-1.0 \mathrm{~V} \mathrm{~s}^{-1}$ (Table 2). The values of $\mathrm{w}^{\mathrm{p}}$ shown in Table 2 confirmed the quasi-reversibility of the system under consideration.

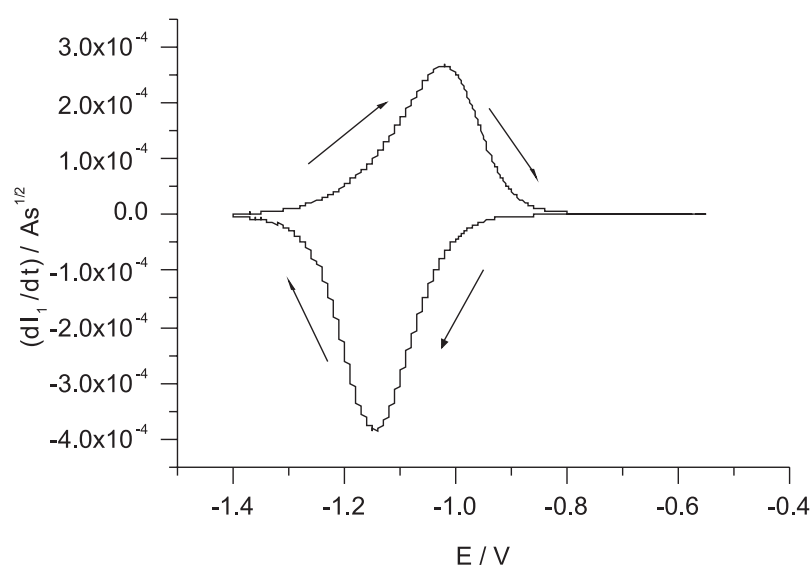

Figure 5. Deconvoluted current of $\left[\left(\mathrm{C}_{6} \mathrm{Me}_{6}\right)\right.$-isocloso-1- $\left.\mathrm{RuB}_{9} \mathrm{H}_{9}\right]$ complex at glassy carbon electrode, sweep rate of $0.2 \mathrm{~V} \mathrm{~s}^{-1}, \mathrm{~T}=21^{\circ} \mathrm{C}$.

The diffusion coefficient was also determined from deconvolution using equation $10,{ }^{38}$

$\mathrm{e}_{\mathrm{p}}=\frac{\alpha \mathrm{n}^{2} \mathrm{~F}^{2} v \mathrm{C}^{\mathrm{bulk}} \mathrm{D}^{1 / 2}}{3.367 \mathrm{RT}}$

where $e_{p}$ is the peak height (in Ampere) of the forward deconvolution sweep and the remaining terms have their usual meanings. Value of the diffusion coefficient estimated from this method is given in Table 1.

Also from combination between convolution and deconvolution transforms the following relationship was deduced:

$$
\begin{aligned}
& \mathrm{n}=\frac{\mathrm{e}_{\mathrm{p}} 3.367 \mathrm{RT}}{\alpha \mathrm{F} v \mathrm{I}_{\lim }} \\
& \mathrm{n}=\frac{0.086 \mathrm{e}_{\mathrm{p}}}{\mathrm{I}_{\lim } \alpha v}
\end{aligned}
$$

where $\mathrm{n}$ is the number of electrons consumed in electrode reaction, and the other parameters have their usual definitions. From equation 11 the number of electrons consumed in the electrode reaction was calculated and found to be $1.13 \mathrm{ca}$. 1 . As shown the number of electrons was determined without knowing the electrode surface area which considers a good, precise and simple method for determining the number of electrons participating in electrode reaction.

\section{Digital simulation}

Digital simulation of the data for cyclic voltammetric experiments was performed on PC computer using EG \& G Condesim software package. The machine was programmed in Pascal. The simulation procedure was carried out using finite differences techniques. ${ }^{42-44}$ Algorithms for the simulation program were coded and implemented into the Condesim software package supplied by EG \& G. A direct test of the determined electrochemical parameters was performed by generating the simulated cyclic voltammogram of $\left[\left(\mathrm{C}_{6} \mathrm{Me}_{6}\right)\right.$-isocloso- $\left.1-\mathrm{RuB}_{9} \mathrm{H}_{9}\right]$ complex using the average values of electrochemical parameters extracted experimentally and comparing it with the voltammogram recorded experimentally. Figure 6 shows a good agreement between the simulated and experimental voltammograms at a scan rate of $0.2 \mathrm{~V} \mathrm{~s}^{-1}$ verifying a moderately fast chemical step (chemical decomposition or conversion of the investigated complex) preceded by a single quasi-reversible electron transfer of the investigated complex.

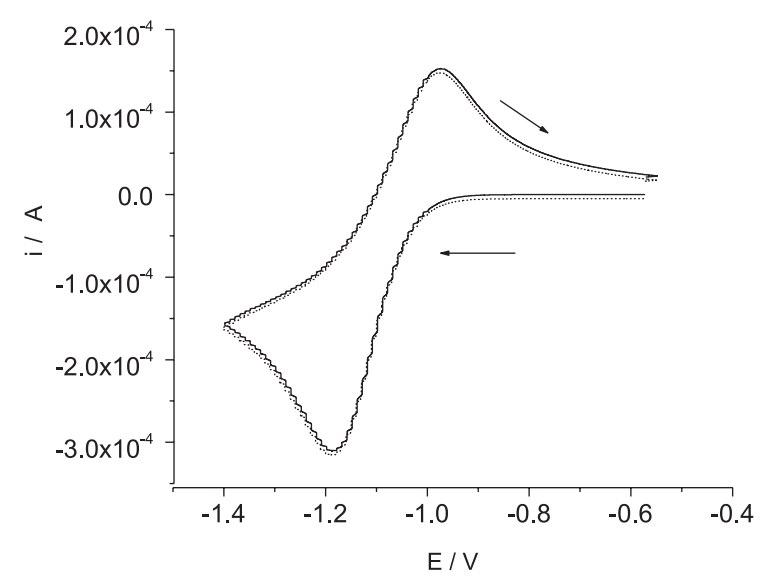

Figure 6. Matching between experimental (——) and simulated voltammograms $(\cdots \cdots \cdots)$ of $\left[\left(\mathrm{C}_{6} \mathrm{Me}_{6}\right)\right.$-isocloso- $\left.1-\mathrm{RuB}_{9} \mathrm{H}_{9}\right]$ complex at a sweep rate of $0.2 \mathrm{~V} \mathrm{~s}^{-1}$ and $\mathrm{T}=21^{\circ} \mathrm{C}$.

\section{Effect of temperature on the rate of electron exchange}

The rate of electron transfer $\left(\mathrm{k}_{\mathrm{s}}\right)$ was investigated as a function of temperature (T). It was found that lowering 


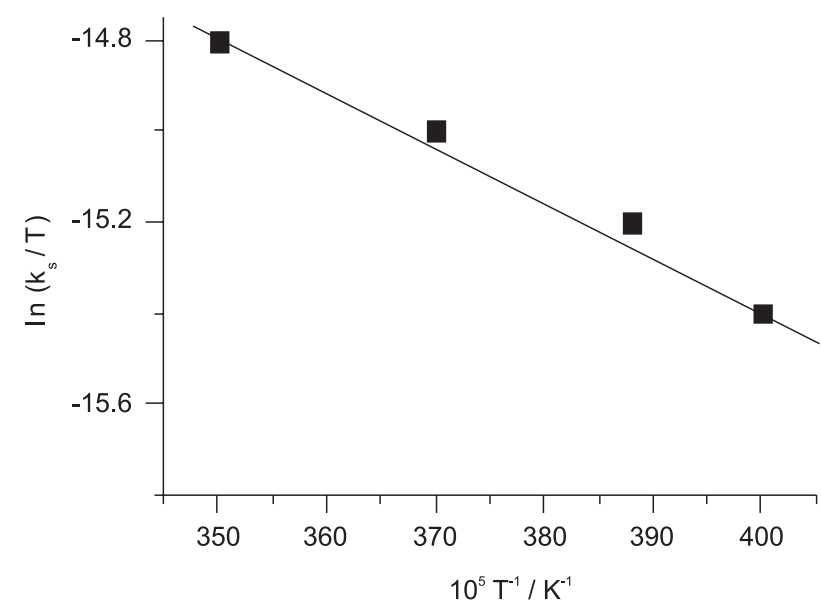

Figure 7. Plot of $\ln \left(\mathrm{k}_{\mathrm{s}} / \mathrm{T}\right)$ vs $1 / \mathrm{T}$ of $\left[\left(\mathrm{C}_{6} \mathrm{Me}_{6}\right)\right.$-isocloso-1- $\left.\mathrm{RuB}_{9} \mathrm{H}_{9}\right]$ complex.

the temperature of the system decrease the rate of electron exchange between electrode and the electroactive species in the electrochemical cell. Figure 7 shows an example response of the plot of $\ln \left(\mathrm{k}_{\mathrm{s}} / \mathrm{T}\right) v s$. 1/T. The enthalpy of activation $\left(\Delta \mathrm{H}^{\neq}\right)$and entropy of activation $\left(\Delta \mathrm{S}^{\neq}\right)$were calculated from the slope and the intercept of the plot using equation 12 ,

$\ln \left(\mathrm{k}_{\mathrm{s}} / \mathrm{T}\right)=\ln (\mathrm{k} / \mathrm{h})-\frac{\Delta \mathrm{H}^{\neq}}{\mathrm{RT}}+\frac{\Delta \mathrm{S}^{\mp}}{\mathrm{R}}$

where $\mathrm{k}$ is the Boltzmann constant, $\mathrm{h}$ is the Plank constant and the other parameters have their usual meanings. Values of $\Delta \mathrm{G}^{\neq}$determined from the values of $\Delta \mathrm{H}^{\neq}$and $\Delta \mathrm{S}^{\neq}$are given in Table 1. The calculated values of $\Delta \mathrm{H}^{\neq}, \Delta \mathrm{S}^{\neq}$and $\Delta \mathrm{G}^{\neq}$indicated that increasing the activation energy barrier upon lowering the temperature of the system which may be attributed to the slow reactant transport at temperature between $-20{ }^{\circ} \mathrm{C}$ and $21^{\circ} \mathrm{C}$ of the electrolyte indicates a larger hindrance to the motion of redox $\left[\left(\mathrm{C}_{6} \mathrm{Me}_{6}\right)\right.$-isocloso$1-\mathrm{RuB}_{9} \mathrm{H}_{9}$ ] species.

\section{Effect of temperature on the diffusion coefficient}

The diffusion coefficient of the investigated Ruthenaborane complex was determined at low temperature in $0.1 \mathrm{~mol} \mathrm{~L}^{-1} \mathrm{TBAP} / \mathrm{CH}_{2} \mathrm{Cl}_{2}$ according to equation 13,45

$\mathrm{i}_{\mathrm{p}}=0.4463\left(\mathrm{~F}^{3} / \mathrm{R}\right)^{1 / 2} \alpha^{1 / 2} \mathrm{n}^{3 / 2} \mathrm{SC} v^{1 / 2}(\mathrm{D} / \mathrm{T})^{1 / 2}$

which associates peak current $\left(i_{p}\right)$ to diffusion coefficient $\mathrm{D}$ when the charge transfer is slow and assuming transfer coefficient $\alpha$ to be 0.5 . Values of the diffusion coefficient determined at various temperatures via equation 13 are listed in Table 3, which indicate decreasing the diffusion coefficient (D) by lowering the temperature of the system.
Table 3. Experimental diffusion coefficients for $\left[\left(\mathrm{C}_{6} \mathrm{Me}_{6}\right)\right.$-isocloso-1$\mathrm{RuB}_{9} \mathrm{H}_{9}$ ] complex extracted from cyclic voltammetry at various values of temperature

\begin{tabular}{cc}
\hline $\mathrm{T} /{ }^{\circ} \mathrm{C}$ & $\mathrm{D} \times 10^{5} /\left(\mathrm{cm}^{2} \mathrm{~s}^{-1}\right)$ \\
\hline 15 & 2.80 \\
5 & 1.70 \\
-5 & 1.05 \\
-20 & 0.51 \\
\hline
\end{tabular}

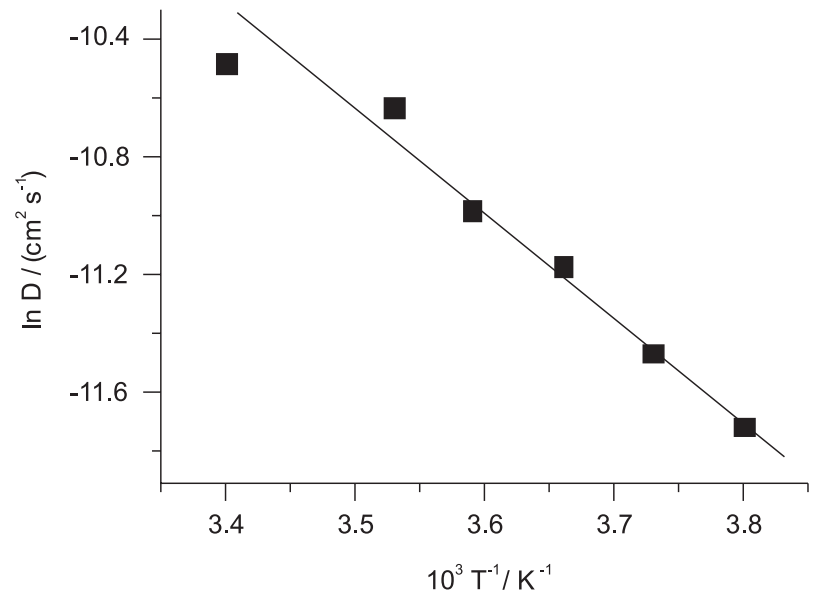

Figure 8. Plot of $\ln \mathrm{D}$ against $1 / \mathrm{T}$ from cyclic voltammetric data of $\left[\left(\mathrm{C}_{6} \mathrm{Me}_{6}\right)\right.$ isocloso-1- $\left.\mathrm{RuB}_{9} \mathrm{H}_{9}\right]$ complex for $-20{ }^{\circ} \mathrm{C} \leq \mathrm{T} \leq 21{ }^{\circ} \mathrm{C}$ using equation 13 .

The diffusion coefficient values for higher temperatures were obtained by extrapolation of $\ln \mathrm{D} v s .1 / \mathrm{T}$ plot (Figure 8). Value of the diffusion coefficient determined from extrapolation method agrees well with that determined from cyclic voltammetry, convolution, deconvolution voltammetry and digital simulation treatments.

\section{Chronoamperometry and chronopotentiometry}

In chronoamperometry experiments, the potential was stepped from the initial potential $(-0.6 \mathrm{~V})$ where no electrode reaction occurs, to a value in the range of $-0.95 \mathrm{~V}$ to $-1.20 \mathrm{~V}$ and the current was recorded as a function of time.

Chronoamperogram of $2.5 \times 10^{-3} \mathrm{~mol} \mathrm{~L}^{-1}$ solution of the complex $\left[\left(\mathrm{C}_{6} \mathrm{Me}_{6}\right)\right.$-isocloso-1- $\left.\mathrm{RuB}_{9} \mathrm{H}_{9}\right]$ in $0.1 \mathrm{~mol} \mathrm{~L}^{-1}$ TBAP $/ \mathrm{CH}_{2} \mathrm{Cl}_{2}$ at a glassy carbon electrode recorded at initial potential step $-0.6 \mathrm{~V}$ and final potential step $-1.075 \mathrm{~V}$, is shown in Figure 9. The rate constant $\mathrm{k}_{\mathrm{f}}$ was calculated from equation $14,{ }^{38}$ where $\mathrm{u}=\mathrm{nFSC}^{\text {bulk }} \mathrm{k}_{\mathrm{f}}(\mathrm{D})^{1 / 2}$ and $\beta=k_{f}(D)^{1 / 2}$. Measurements of both the intercept at $I_{1}$ $=0$ and the slope of the linear plot of $\mathrm{i}(\mathrm{t})$ versus $\mathrm{I}_{1}$ give $\mathrm{k}_{\mathrm{f}}$.

$\mathrm{i}(\mathrm{t})=-\beta \mathrm{I}_{1}+\mathrm{u}$ 


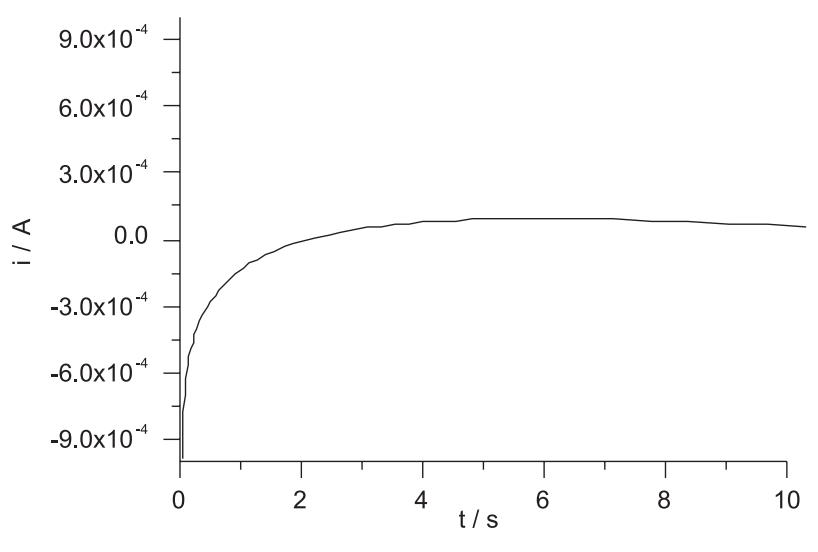

Figure 9. Chronoamperogram of $\left[\left(\mathrm{C}_{6} \mathrm{Me}_{6}\right)\right.$-isocloso-1- $\left.\mathrm{RuB}_{9} \mathrm{H}_{9}\right]$ complex at glassy carbon electrode and $\mathrm{T}=21^{\circ} \mathrm{C}$.

Here, the fundamental relationship between the rate constant of the electron transfer and the potential of the electrode is discussed in terms of the Butler-Volmer treatment which can be expressed in the form of equation $15.38,46$

$\ln \mathrm{k}_{\mathrm{f}}=\frac{\alpha \mathrm{nF}}{\mathrm{RT}}\left(\mathrm{E}_{\mathrm{f}}-\mathrm{E}^{\mathrm{o}^{\prime}}\right)+\ln \mathrm{k}_{\mathrm{s}}$

Value of $\alpha$ was estimated from slope of the linear plot of $\ln \mathrm{k}_{\mathrm{f}} v s .\left(\mathrm{E}_{\mathrm{f}}-\mathrm{E}^{\mathrm{o}^{\prime}}\right)$ and was found to be 0.42 , while value of the standard heterogeneous rate constant $\mathrm{k}_{\mathrm{s}}$ was estimated at the point at which $\mathrm{E}_{\mathrm{f}}=\mathrm{E}^{\mathrm{o}^{\prime}}$ and was found to be $3.65 \times 10^{-3} \mathrm{~cm} \mathrm{~s}^{-1}$. Both values are compared well with those obtained from cyclic voltammetry and digital simulation data (Table 1).

Chronopotentiogram of $2.5 \times 10^{-3} \mathrm{~mol} \mathrm{~L}^{-1}$ solution of the complex $\left[\left(\mathrm{C}_{6} \mathrm{Me}_{6}\right)\right.$-isocloso-1- $\left.\mathrm{RuB}_{9} \mathrm{H}_{9}\right]$ recorded in $0.1 \mathrm{~mol} \mathrm{~L}^{-1} \mathrm{TBAP} / \mathrm{CH}_{2} \mathrm{Cl}_{2}$ at a glassy carbon electrode displayed only one reduction transition time in agreement with the single reduction voltammetric peak. The chronopotentiometric transition time was analyzed via equation $16,{ }^{38}$

$\mathrm{I}_{\lim }=2 \mathrm{i}_{\mathrm{c}}\left\{\mathrm{t}_{\mathrm{s}} / \pi\right\}^{1 / 2}=\left(\mathrm{nFAC}^{\text {bulk }} \mathrm{D}^{1 / 2}\right)$

where $\mathrm{i}_{\mathrm{c}}$ is the polarization current, $\mathrm{t}_{\mathrm{s}}$ is the transition time of the investigated complex, and the other symbols have their usual definitions. The obtained value of diffusion coefficient D agrees well with that obtained from each of cyclic voltammetry, $\mathrm{I}_{1}$ convolution, deconvolution voltammetry and digital simulation measurements (Table 1).

Based on the above electrochemical investigations, the reductive electrode processes of $\left[\left(\mathrm{C}_{6} \mathrm{Me}_{6}\right)\right.$-isocloso$\left.1-\mathrm{RuB}_{9} \mathrm{H}_{9}\right]$ complex at the glassy carbon electrode can be expressed as:

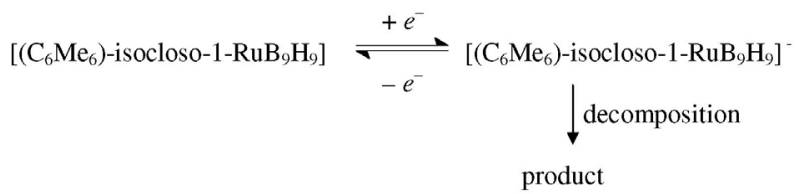

\section{Conclusions}

In this article the electrochemistry of hexamethylbenzene isoclosoruthenium-borane complex was investigated at a glassy carbon electrode in $0.1 \mathrm{~mol} \mathrm{~L}^{-1}$ tetrabutylammonium perchlorate dissolved in mythylene chloride, at different temperatures using cyclic voltammetry, convolutive voltammetry, chronoamperometry and chronopotentiometry techniques. The chemical and electrochemical parameters of the investigated complex have been determined experimentally and confirmed theoretically via digital simulation method. The effect of temperature on the heterogeneous rate constant of the electron exchange and the diffusion coefficient were explained and discussed. The values of the free energy of activation $\left(\Delta \mathrm{G}^{\#}\right)$, the enthalpy of activation $\left(\left(\Delta \mathrm{H}^{\#}\right)\right.$ and the entropy of activation $\left(\Delta \mathrm{S}^{\#}\right)$ of the investigated complex were calculated from the plot of $\ln \left(\mathrm{k}_{\mathrm{s}} / \mathrm{T}\right)$ versus $1 / \mathrm{T}$. The electrode reaction was found to proceed as moderate fast charge transfer followed by chemical reaction, i.e., EC mechanism.

\section{Acknowledgments}

The authors are grateful to prof. J. D. Kennedy, School of Chemistry, University of Leeds., for preparing and providing the investigated complex.

\section{References}

1. Hawthorne, M. F.; Maderna, A.; Chem. Rev. 1999, 99, 3421.

2. Bould, J.; Kennedy J. D.; Thornton-Pett, M.; J. Chem. Soc., Dalton Trans. 1992, 563.

3. Kennedy, J. D.; Satibr, B. In Current Topics in the Chemistry of Boron; Kabalka, G. W., ed., Royal Society of Chemistry: Cambridge, 1994, pp. 285-292.

4. Kennedy, J. D. In The Borane-Carborane-Carbocation Continuum; Casanova, J., ed., Wiley: New York, 1998, ch. 3, pp. 85-116.

5. Stibr, B.; Kennedy, J. D.; Drdakova, E.; Thorntonpett, M.; J. Chem. Soc., Dalton Trans. 1994, 229.

6. Kim, Y. H.; Cooke , P. A.; Rathb, N. P.; Barton, L.; Greatrex, R.; Kennedy, J. D.; Pett, M. T.; Inorg. Chem. Commun. 1998, 1,375 .

7. Bould, J.; Kennedy, J. D.; Thornton-Pett, M.; J. Chem. Soc., Dalton Trans. 1992, 563. 
8. Callahan, K. P.; Evans, W. J.; Lo, F. Y.; Strouse, C. E.; Hawthorne, M. F.; J. Am. Chem. Soc. 1975, 97, 296.

9. Morris, J. H.; Reed, D.; J. Chem. Res., Miniprint 1980, 282, 3567.

10. Drummond, A.; Kauy, J. F.; Morris, J. H.; Reed., D. J.; J. Chem. Soc., Dalton Trans. 1980, 284.

11. Kay, J. F.; Morris, J. H.; Reed, D.; J. Chem. Soc. 1980, 1917.

12. Morris, J. H.; Reed, D.; Inorg. Chim. Acta 1981, L7, 54.

13. Morris, J. H.; Reed, D.; J. Chem. Res., Miniprint 1980, 282, 3567.

14. Dolan, P. J.; Kindsvater, J. H.; Peters, D. J.; Inorg. Chem. 1976, $15,2170$.

15. Morris, J. H.; Reed, D. J.; J. Chem. Res., Synop. 1980, 380.

16. Bowden; W. J.; J. Electrochem. Soc. 1982, 129, 1249.

17. Wong, E. H.; Kabbani, R. M.; Inorg. Chem. 1980, 19, 451.

18. Seidle, A. R.; Todd, L.; J. Inorg. Chem. 1976, 15, 2838.

19. Hettrich, R.; Kaschke, M.; Wadepohl, H.; Weinmann, W.; Stephan, M.; Pritzkow, H.; Siebert, W.; Hyla-Kryspin, I.; Gleiter, R.; Chem. Eur. J. 1996, 2, 487.

20. Bould, J.; Kennedy, J. D.; Thornton-Pett, M.; J. Chem. Soc., Dalton Trans. 1992, 563.

21. Stibr, B.; Kennedy, J. D.; Drdakova, E.; Thornton-Pett, M.; J. Chem. Soc., Dalton. Trans. 1993, 2335.

22. Doetsch, G.; Laplace Transformation, Dover: New York, 1953. 23. El-Hallag, I. S.; Ph.D. Thesis, Tanta University, Egypt, 1991.

24. Woodard, F. E.; Goodin, R. D.; Kinlen P. J.; Anal. Chem. 1984, $56,1920$.

25. Lawson, R. J.; Maloy, J. T.; Anal. Chem. 1974, 46, 559.

26. Nadjo, L.; Saveant, J. M.; J. Electroanal. Chem. 1973, 48, 113.

27. Leddy, J.; Bard, A. J.; J. Electroanal. Chem. 1985, 189, 203.

28. Oldham, K. B.; J. Electroanal. Chem. 1983, 9, 145.

29. Ammar, F.; Saveant, J. M.; J. Electroanal. Chem. 1973, 47, 215.
30. Kennedy, J.; University of Leeds, personal communication.

31. El-Hallag, I. S.; Ghoneim, M. M.; Monatsh. Chem. 1996, 127, 487.

32. Nicholson, R. S.; Shain, I.; Anal. Chem. 1964, 36, 706.

33. Gaudiello, J. G.; Wright, T. C.; Jones, R. A.; Bard, A. J.; J. Am. Chem. Soc. 1985, 107, 888.

34. Nichlson, R. S.; Anal. Chem. 1965, 37, 1351.

35. Imbeaux, J. C.; Saveant, J. M.; J. Electroanal. Chem. 1973, 44, 169.

36. Dobson, I. D.; Taylor, N.; Tipping, L. R. H. In Electrochemistry, Sensor and Analysis, Elsevier: Amsterdam, 1986, pp. 61-75.

37. El-Hallag, I. S.; Ghoneim, M. M.; Hammam, E.; Anal. Chim. Acta 2000, 414, 173.

38. Ghoneim, M. M.; El-Hallag, I. S.; Monatsh. Chem. 1999, 130, 525.

39. Oldham, K. B.; Anal. Chem. 1983, 9, 145.

40. El-Hallag, I. S.; Hassanein, A. M.; Ghoneim, M. M.; Monatsh. Chem. 1995, 126, 1075.

41. El-Daly, S. A.; El-Hallag, I. S.; Ebied, E. M.; Ghoneim, M. M.; Chin. J. Chem. 2009, 27, 241.

42. Feldberg, S. W.; Electroanal. Chem. 1969, 3, 199.

43. Feldberg, S. W. In Electroanalytical Chemistry; Bard, A. J., ed., Marcel Dekker: New York, 1969.

44. Britz, D.; Digital Simulation in Electrochemistry, Springer: Berlin, 1981.

45. Richardson, J. N.; Harvey, J.; Murray, R. W.; J. Phys. Chem. 1994, 98, 13396.

46. Saveant, J. M.; Tessier, D.; Electranal. Chem. 1975, 61, 251.

Received: January 28, 2009

Web Release Date: September 25, 2009 